2015, volume 4, issue 1

Kościelniak H., Skowron-Grabowska B., Łęgowik-Świącik S., Łęgowik-Małolepsza M. (2015). The analysis of the capacity of the selected measures of decision-making models in companies. Copernican Journal of Finance \& Accounting, 4(1), 131-145. http://dx.doi.org/10.12775/CJFA.2015.009

\author{
Helena Kościelniak* \\ Czestochowa University of Technology \\ Beata Skowron-Grabowska** \\ Czestochowa University of Technology \\ SYLWIA KĘGOWIK-ŚWIĄCIK** \\ Czestochowa University of Technology \\ Matgorzata Kęgowik-Matolepsza \\ Czestochowa University of Technology
}

\title{
THE ANALYSIS OF THE CAPACITY OF THE SELECTED MEASURES OF DECISION-MAKING MODELS IN COMPANIES
}

Keywords: decision-making models, decision making, processes organizational - financial of enterprises.

J E L Classification: G32, L21, L61, M21.

Abstract: The paper aims at the analysis of the information capacity of selected instruments of the assessment of decision-making models in the analyzed companies. In the paper there are presented the idea and concepts of decision-making models. There have been discussed the selected instruments of the assessment of decision-making models

Date of submission: March 29, 2015; date of acceptance: May 7, 2015.

* Contact information: helenak@zim.pcz.pl, Czestochowa University of Technology, J.H. Dąbrowskiego 69, 42-201 Częstochowa, Polnad, phone: 343255211.

** Contact information: beatas@zim.pcz.czest.pl.

*** Contact information: slegowik@zim.pcz.pl. 
in enterprises. In the final part of the paper there has been held the quantification of decision-making models in the investigated cement industry companies. To meet the objective of the paper there have been used literature studies and descriptive analysis. To specify the strength and direction of interactions between the parameters of the selected measures there has been calculated Pearson correlation coefficient. The problem of information capacity of the instruments of the assessment of decision-making models is important and up-to-date due to its impact on the effectiveness of management of the analyzed enterprises and the possibility to generate value added.

Translated by Małgorzata Łęgowik-Małolepsza

\section{IIITTRODUTION}

The aim of the paper is to examine the information capacity of the selected measures of decision-making models in the course of organizational and financial processes of the cement industry companies. The applied research method is multiple discriminant analysis carried out using the Altman Z-score model. To assessment of information capacity of the selected measures of decisionmaking models in organizational and financial processes of the cement industry companies has been applied Pearson correlation coefficient.

In the theory of the organization the model recognizes the characteristics of the reality of the economic system which are crucial for understanding behavioral, institutional, technical and organizational and functional relationships that occur in the framework of this reality. The model is not only to present the reality in a simplified manner, but also to build the assumptions of the activity, patterns of behavior, the selection of some basic resources along with the indication of the cause and effect links between the components of the model of different processes of business activity of enterprises.

The subject of the decisions taken amounts to individual processes of enterprises. The process is understood as a set of activities performed in a specific sequence, which aim to produce a product or service of a certain acceptable value. Enterprises that want to achieve success on the market must operate so as to generate value added which will allow to generate the expected financial results. Taking into account the above statements, it is assumed in the paper that organizational and financial processes include the whole of the managerial activities connected with ordering, grouping, analyzing, and assigning employees specific tasks based on the possessed information to optimize activities connected with financial service of enterprises, their current and future activity. 


\section{THE DEFINITION AND CONCEPTS OF DECISION-MAKING MODELS}

Model concepts have gained in popularity, which has been confirmed by many publications in the field of the analyzed subject in recent years. The etymology of the concept originates from the Latin word "modus" and it means "the pattern according to which something is performed, the object being a model or a copy of a specific object, made in a smaller size" (Sobol 2000). The fact of which part of the reality is copied by the model, among others, depends on the research problem, the subject and object of the research, the scope of the research, the period included by the research and the applied research methods and techniques (Ackoff, Churchman 1957).

In management theory, decision-making models are a conceptual tool of enterprise management being, "to a particular enterprise, a unique way of operating on the market, which provides the maintenance of a long-term competitive advantage by providing clients with value added, understood as satisfying or even exceeding expectations as to broadly understood quality of products or services" (Brdulak 2011, Skowron-Grabowska 2014). In accordance with the dynamic approach in management theory they are the tool presenting the logic of operations of enterprises in a particular field, including the set of elements and relationships between the elements (Nogalski 2009, Konovalova 2014). The rational decision-making model is the classic in the subject literature (Jacobson, Choi 2008). The rational model is particularly applicable in reasoning a priori, in which it is assumed that there is a simple solution to the problem which only needs to be discovered (Griffin 2000 270, Stoner, Freeman, Gilbert 2001, 247).

Adopting rational decisions requires from a decision-maker to possess wide knowledge and complete information on the decision-making situation, possible alternative solutions, evaluated with respect to the achievement of the objective and implementation of introductory activities (Grudzewski, Hejduk 2006). While assessing the implemented solutions there should be evaluated the willingness of the manager to take risk and the ability to deal with the imposed constraints (Bittel 2002). If the effective implementation of decisions is conditioned by the involvement of a wider circle of stakeholders, it is necessary to lead to such commitment (Stewart 2002).

Decision-making models are a tool enabling the implementation of decisions and they allow for the adaptation of the best solutions in particular conditions. It should be remembered, though, that the changeability of the enterprise environment, both exogenous and endogenous, is the subject to permanent chang- 
es. This changeability of the environment brings about "travelling of the model", leading to transformations of decision-making models and developing their classifications (Magretta 2002).

\section{MEASURES AND ASSESSMENT TOOLS AS THE ELEMENTS OF DECISION-MAKING MODELS}

Decision-making is an immanent feature of management. In the subject literature there are a lot of definitions of management. All of them underline the significance of the achievement of goals and the intended effects (Krupski, Niemczyk, Stańczyk-Hugiet 2009). The achievement of the intended effectiveness involves making a range of managerial decisions based on reliable information (Akerlof 1970), on the basis of which the assessment of the course of economic processes is possible (Sudoł 2011).

The tools used in decision-making models frequently concentrate on the ways of solving financial problems. An essential source of information on the results of the activity of business entities are financial statements. The tool of processing information from financial statements is the financial analysis. The analysis is a scientific procedure that involves the study of components of the whole and considering these components separately (Cebrowska 2006). The financial analysis is one of the sections of economic analysis. Its scope depends on the entity conducting the analysis, objectives of its performance and availability and detailed information essential for its performance (Skoczylas, Waśniewski 2005).

An effective tool of the assessment of selection alternatives in decisionmaking models, apart from the analysis of financial statements, is ratio analysis (Cebrowska 2006). The tool for this analysis are indicators corresponding to the relationships of the respective values included in balance sheet, profit and loss account, cash flow statement and statement of changes in equity (Bednarski 2007). Financial indicators are the parameter of the value flow in enterprises and the carrier of information for different groups of recipients (Kowalczyk, Kusak 2006).

An efficient tool of managerial decision-making is the Altman Z-score model, included the group of the second generation indicators. The concept of E. I. Altman belongs to the group of multiple discriminant methods indicating the signs of bankruptcy of enterprises. This concept consists in studying information included in financial statements of the investigated entities using spe- 
cific ratios. E. I. Altman proposed a few options of so called function. The original E. I. Altman's concept came into being in 1968 and had the following form (Altman 1968):

Formula 1. The first formula of the Altman Z-score model

$$
\mathrm{Z}=1.2 \mathrm{X}_{1}+1.4 \mathrm{X}_{2}+3.3 \mathrm{X}_{3}+0.6 \mathrm{X}_{4}+1.0 \mathrm{X}_{5}
$$

$\mathrm{X}_{1}$ - working capital /total assets

$\mathrm{X}_{2}$ - retained earnings / total assets

$\mathrm{X}_{3}$ - earnings before interest and taxes / total assets

$\mathrm{X}_{4}$ - market value of equity / book value of foreign capital

$\mathrm{X}_{5}-$ net sales / total assets.

Conducting the empirical research using the Altman Z-score model there is obtained information in the research group on enterprises threatened with bankruptcy and solvent companies. The research result refers to the accepted boundaries of the classification of companies and individual groups of classification. The concept which has been used in the present paper was established in 1983 and has been reflected in the following formula (Altman 1984):

Formula 2. The second formula of the Altman Z-score model $\mathrm{Z}^{\prime}=0.717 \mathrm{X}_{1}+0.847 \mathrm{X}_{2}+3.107 \mathrm{X}_{3}+0.420 \mathrm{X}_{4}+0.998 \mathrm{X}_{5}$

The presented model is known as Zeta-function or Z-Score and is based on the parameters of the original concept of E. I. Altman except for variable X4, which took the following form: X4 - carrying (book) value of equity / book value of foreign capital (Altman, Hotchkiss 2007). Redefining Zeta function caused that the Altman concepts could be used by a larger number of enterprises. The original concept of E. I. Altman required the knowledge of the market value of equity of the analyzed company. The Z-Score model, based on carrying (book) value of equity was addressed to enterprises which were not able to determine the market value of equity.

Another version of the $Z$-score model consists in eliminating the final variable of the Z' function, which is the parameter X5. Such a change is driven by the fact that asset turnover ratio $\mathrm{X} 5$ is significantly dependent of the market the analyzed company operates on. The elimination of the variable X5 made the Z' function a universal and cross-sector method of early prediction of bankruptcy 
in the investigated company, and the Z" function took the following form (Altman, Hotchkiss 2007):

Formula 3. The third formula of the Altman Z-score model

$$
Z^{\prime \prime}=6.56 \mathrm{X}_{1}+3.26 \mathrm{X}_{2}+6.72 \mathrm{X}_{3}+1.05 \mathrm{X}_{4}
$$

The Altman models, apart from advantages, also have some drawbacks. The presented concepts of E. I. Altaman depict only the selected area of the researcher's studies and aim at the presentation of some exemplary concepts of predicting bankruptcy of enterprises.

Choosing the Altman model to assess selection alternatives in decision-making models was determined by the information capacity of these parameters (Stachowicz 2002) since it characterizes organizational and financial phenomena (Kościelniak 2008) and is an efficient research tool, enabling the penetration of information channels. The presented Altman model is not a model of the latest generation but it is characterized by simplicity and rapidity of measurement, which results in reducing the time of decision-making.

Tools and measures of the assessment of selection alternatives of decisionmaking may not only support decision-making processes in the assessment of regularities of use of the possessed resources and achievement of the assumed objectives but also they should enable the formation of model solutions. The selection of appropriate measures to assess selection alternatives of decisionmaking plays an important role in planning future directions of the company development.

\section{THE RESEARCH METHODOLOGY AND THE COURSE OF THE RESEARCH PROCESS}

The empirical research was conducted in two enterprises of the cement industry operating in Poland and belonging to the international concerns of the cement industry, on the basis of random sampling, which conventionally are referred to as $\alpha_{1}, \alpha_{2}$. The assessment of decision-making models in organizational and financial processes in the cement industry was made on the basis of the financial statements of the companies $\alpha_{1}, \alpha_{2}$ in years 2005-2013. From the point of view of the accomplishment of the objectives of the present paper, the most useful research tool, enabling ordering, grouping and comparability of heterogeneous areas which are the cement industry companies is multiple discriminant analysis. 
To quantify decision-making models in organizational and financial processes in the cement industry companies there was carried out the two-stage empirical research. In the first stage there was used the multiple Altman model enabling early prediction of risk symptoms related to the continuation of the activity, which was determined by the international capital structure of the analyzed companies.

To quantify decision-making models in organizational and financial processes in the cement industry companies there was used the second formula of the Altman model on account of the fact that it is used by the surveyed companies. The complexity of individual procedures in the Altman model provides the conditions for conducting an objective analysis of the financial condition of the investigated companies. The possibilities of application of the discussed model allow for the quantification of the selected areas of the activity of the analyzed companies and the obtained information will be used to diagnose the course of organizational and financial processes and to evaluate their time fluctuations. The empirical research using the Altman model was carried out in the two cement industry companies in the following order $\alpha_{1}, \alpha_{2}$.

Table 1. The evolution of ratios in the Altman model for the company $\alpha_{1}$

\begin{tabular}{|c|c|c|c|c|c|c|c|c|c|}
\hline \multirow{2}{*}{ Formula of the ratio in the company $\alpha_{1}$} & \multicolumn{9}{|c|}{ Financial year } \\
\hline & 2005 & 2006 & 2007 & 2008 & 2009 & 2010 & 2011 & 2012 & 2013 \\
\hline $\mathrm{X}_{1}=$ working capital/total assets & 0.19 & 0.28 & 0.29 & 0.08 & -0.02 & -0.1 & -0.05 & 0.06 & 0.07 \\
\hline $\mathrm{X}_{2}=$ net profit - dividend $/$ total assets & 0.06 & 0.12 & 0.09 & -0.01 & -0.02 & -0.01 & 0.02 & 0.04 & 0.05 \\
\hline$X_{3}=$ gross profit - interest paid $/$ total assets & 0.17 & 0.23 & 0.31 & 0.34 & 0.25 & 0.17 & 0.19 & 0.21 & 0.23 \\
\hline $\mathrm{X}_{4}=$ book value of equity / value of foreign capital & 9.58 & 7.6 & 6.62 & 3.45 & 2.36 & 1.69 & 1.6 & 1.8 & 1.8 \\
\hline$X_{5}=$ sales revenue $/$ total assets & 0.5 & 0.54 & 0.66 & 0.68 & 0.54 & 0.46 & 0.56 & 0.6 & 0.62 \\
\hline$Z^{\prime}=$ Altman Z-score in the company $\alpha_{1}$ & 5.24 & 4.75 & 4.69 & 3.23 & 2.28 & 1.62 & 1.8 & 2.08 & 2.18 \\
\hline
\end{tabular}

S o u r c e : Author's own study.

The first ratio of the Altman model is financial liquidity (X1) determined on the basis of working capital. The ratio X1 in the company $\alpha_{1}$ provides information on what proportion of current assets was not financed by current liabilities. In years 2005-2007 liquidity ratio remained at a very high level (the same as current financial liquidity ratio). In 2008 there was a sharp decline in liquidity of the surveyed company, which was due to the takeover of highly indebted 
entities. The investment decisions resulted in the trend reducing financial liquidity until the year 2010. From 2011 the ratio indicated the improvement in ability of the company to cover liabilities. The calculations made proved that in 2006 there was an increase in the value of the cumulated return on assets ratio, which resulted from a higher portion of retained earnings in the company $\alpha_{1}$ compared to an increase in assets. In years 2007-2009 there was a sharp decline in the ratio value, which was the result of payment of high dividends. In years 2010 - 2013 there was an increase in the value of cumulated return on assets ratio, indicating an increase in the accumulation of profits saved in the course of the business activity.

Return on assets ratio is the most important parameter forming the Altman model. In the company $\alpha_{1}$ assets are the tangible basis for running a business activity. The level of the involvement of assets in generating the financial result in the company $\alpha_{1}$ demonstrated an upward trend in 2008. In 2009 there was a decline in the ratio value reflecting a decrease in the financial result. A downward trend continued until 2010. In years 2011-2013 there was an increase in the ratio value indicating the improvement in the efficiency of management of assets and obtaining a better financial result.

The effectiveness of using equity indicates what is the share of the company equity in the liabilities. In the company $\alpha_{1}$ there was a steady decline in the ratio level (2005-2011), which indicated decision-making in the field of business financing. In years 2011-2013 the ratio value was more than 1, which indicated solvency of the company, though, there was a clearly noticeable trend of moving away from financing the business with equity for the benefit of funding with foreign capital. At the same time, it should be noted that the Golden Rule of financing was not violated.

The study of asset turnover aims at the evaluation of the effectiveness of management of assets. In the company $\alpha_{1}$ the value of asset turnover ratio showed an upward trend in years 2005-2008, which indicated a steady increase in the involvement of assets in generating sales revenue. In years 20092010 there was a decline in sales revenue, which was reflected in a decrease in the level of asset turnover ratio. In years 2011-2013 there was an increase in the level of asset turnover ratio, indicating the acceleration of asset restoration by the achieved sales revenue.

Analyzing solvency of the company $\alpha_{1}$ and the ability to continue the activity based on the research by the Altman model, it can be observed that in the company $\alpha_{1}$ there was a downward trend. In years 2005-2008 the value of the 
Altman model indicated that the company $\alpha_{1}$ belonged to the "non-bankrupt" group. The evolution of the value in the Altman model in years 2009-2013 was in the sphere of ambiguous classification. Admittedly, there was a decline in financial liquidity (X1) and profitability (X3) in the discussed period but in the company $\alpha_{1}, 2010$ was a critical year. On the other hand, in subsequent years, both profitability (X3) and asset turnover (X5) improved, therefore, it can be concluded that the risk of bankruptcy did not pose a threat to the company $\alpha_{1}$.

Another stage of the research includes the verification of the Altman model in the company $\alpha_{2}$. In Table 2 . There is presented the evolution of the level of ratios in the Altman model for the company $\alpha_{2}$ in the analyzed period.

Table 2. The evolution of ratios in the Altman model for the company $\alpha_{2}$

\begin{tabular}{|l|c|c|c|c|c|c|c|c|c|}
\hline \hline \multicolumn{1}{|c}{ Formula of the ratio in the company $\alpha_{2}$} & \multicolumn{9}{c|}{ Financial year } \\
\cline { 2 - 10 } & $\mathbf{2 0 0 5}$ & $\mathbf{2 0 0 6}$ & $\mathbf{2 0 0 7}$ & $\mathbf{2 0 0 8}$ & $\mathbf{2 0 0 9}$ & $\mathbf{2 0 1 0}$ & $\mathbf{2 0 1 1}$ & $\mathbf{2 0 1 2}$ & $\mathbf{2 0 1 3}$ \\
\hline \hline X1 = working capital / total assets & -0.08 & 0.06 & -0.07 & -0.13 & 0.01 & -0.14 & 0.06 & 0.04 & 0.05 \\
\hline X2 = net profit - dividend / total assets & 0.09 & 0.11 & 0.09 & -0.03 & -0.01 & -0.02 & 0.03 & 0.303 & 0.02 \\
\hline X3 = gross profit - interest paid / total assets & 0.2 & 0.11 & 0.12 & -0.05 & -0.07 & -0.06 & 0.02 & 0.02 & 0.01 \\
\hline X4 = book value of equity / value of foreign capital & 1.8 & -0.01 & 0.08 & 0.04 & 0.01 & 0.03 & 0.09 & 0.08 & 0.07 \\
\hline X5 = sales revenue /total assets & 0.85 & 0.95 & 1.14 & 1.04 & 0.96 & 0.95 & 1.09 & 0.95 & 0.9 \\
\hline Altman Z-score in the company $\alpha_{2}$ & 2.24 & 1.42 & 1.57 & 0.78 & 0.74 & 0.66 & 1.26 & 1.10 & 1.01 \\
\hline \hline
\end{tabular}

S o u r c e : Author's own study.

The analysis of financial liquidity conducted on the basis of working capital in the company $\alpha_{2}$ shows a similar trend as in the case of the determination of financial liquidity using different categories of current assets, referred to current liabilities. In the company $\alpha_{2}$ working capital represents a small percentage of total assets. In 2006 the value of liquidity ratio was at a relatively high level. In years 2007-2008 there was a sharp deterioration in the financial condition of the company in question. In 2009 there was an improvement in the ability to meet liabilities but in 2010 there was another decline in the financial liquidity of the company $\alpha_{2}$. In 2011 the level of liquidity began to stabilize, however, in years 2012-2013 the level of financial liquidity ratio indicated low ability to meet liabilities by the company $\alpha_{2}$.

In the company $\alpha_{2}$ in 2006 there was an increase in the accumulation of profits generated by the assets. In 2007 there was a slight decrease in the level of 
the ratio to the level of 2005. In 2008 there was a sharp decline in the level of cumulated return on assets ratio, indicating a significant decrease in the ratio of retained earnings compared to assets involved in generating profits. An unfavorable situation continued until 2010. In 2011 there was a substantial increase in the ratio value, which indicated that the level of retained earnings in the company was relatively higher in relation to an increase in assets, however a decline in sales in years 2012-2013 resulted in a further decrease in the accumulation of profits generated by the assets in the company $\alpha_{2}$.

The efficiency of using assets in the company $\alpha_{2}$ declined in 2006. In 2007 there was an increase in return on assets ratio. The crisis in 2008 and the realized investments resulted in a sharp decline in return on assets in the company $\alpha_{2}$. Poor condition of the company continued until 2010. In 2011 the company again began to achieve a positive financial result from the assets involved, which was reflected in an increase in gross return on assets ratio with interest. The improvement in return on assets was the result of the decisions taken on the level of costs borne and the produced revenue and the suspension of risky investments. A decline in the level of the financial result in years 2012-2013 resulted in a decrease in return on assets in the company $\alpha_{2}$.

The evolution of the level of capital efficiency ratio in the company $\alpha_{2}$, indicates unfavorable (investment) decisions in 2006. They resulted in significant weakening of the financial condition of the company posing a risk of the loss of liquidity. The decisions of 2006 along with no prediction of the economic crisis by the company in question resulted in long-term disturbances in the capital structure. In years 2011-2013 there was an improvement in the financial condition of the surveyed company, which was the result of generating profits in that period.

The performance measured with asset turnover ratio in the company $\alpha_{2}$ indicates that in years 2005-2007 there was an increase in the involvement of assets in generating sales revenue. In 2008 there was a decline in the ratio value and a downward trend continued until 2010. In 2011 there was an improvement in the effectiveness of using the assets for generating sales revenue, there was an increase in asset turnover and the efficiency of using equity. In years 2012-2013 a decline in the level of sales in the company $\alpha_{2}$ resulted in a decrease in the level of asset turnover ratio.

Z'-score in the Altman model calculated for the company $\alpha_{2}$ to assess the solvency and ability to continue the activity indicated that the investigated company coped with many decision-making problems. The level of the Altman 
model in the company $\alpha_{2}$ in years 2006-2013 indicated the occurrence of risks in the area of the continuation of the activity of the analyzed company.

In years 2008-2010 the values in the Altman model for the company $P_{3}$ suggested a bankrupt. However, in 2011 there was an upward trend suggesting slow recovery from a crisis situation. Undoubtedly, such an image of the analyzed company was created by the impact of investments made in 2006 and the fact that it was not predicted that the crisis would affect the cement industry so significantly. A decline in the level of sales caused by the overall downward trend on the market again brought about a decrease in the level of the Altman Z'-score in the company $P_{3}$, which brings about that it is impossible to clearly qualify the investigated company to the appropriate group.

\section{THE ASSESSMENT OF USING DECISION-MAKING MODELS}

\section{IN ORGANIZATIONAL AND FINANCIAL PROCESSES OF THE CEMENT INDUSTRY}

In order to assessment of information capacity of the researches measures of decision-making models the strength and direction of linear relationship between decision-making factors were examined by Pearson correlation coefficient. Studies are designed to show the main parts of the decision-making process in researches companies.

To examine the strength and direction of linear relationship between the level of return on equity and sales revenue, asset turnover and equity multiplier in the investigated companies there were calculated the values of Pearson's correlation coefficient. The values of Pearson's correlation coefficient are within a range of $\langle-1,1\rangle$. A strong correlation occurs when a coefficient value fluctuates around 1 or -1 , a weak correlation occurs when coefficient value approaches 0 . The sign of the coefficient indicates the direction of the relationship between the variables under consideration. In the studies, it is assumed that the correlation value in the following ranges amounts to 0 to 0.3 - weak correlation, 0.3 to 0.6 - relatively strong correlation, 0.6 to 1 - strong or very strong correlation.

At the subsequent stage there was examined the strength and direction of correlation between the Altman Z'-score and its components (Table 3). In the company $\alpha_{1}$ there can be noticed a very strong positive correlation between the value of the Altman Z'-score and financial liquidity and capital market efficiency. This means that in the company $\alpha_{1}$ an increase in solvency is accompanied by an increase in financial liquidity and an increase in the share of the market 
value of equity in the structure of total liabilities. A strong correlation occurs between the Altman Z-score and cumulated return on assets. This indicates that an increase in solvency in the company $\alpha_{1}$ occurs along with an increase in retained earnings in relation to total assets.

Table 3. Pearson's correlation coefficient between individual measures of the Altman model for the company

\begin{tabular}{|l|c|c|}
\hline \multirow{2}{*}{ Pearson's correlation coefficient between } & \multicolumn{2}{|c|}{ The Altman Z'-score } \\
\cline { 2 - 3 } & $\alpha_{1}$ & $\alpha_{2}$ \\
\hline \hline X1 = Financial liquidity & 0.91 & 0.06 \\
\hline X2 = Cumulated return on assets & 0.71 & 0.85 \\
\hline X3 = Return on assets & 0.23 & 0.97 \\
\hline X4 = Capital market efficiency & 0.98 & 0.79 \\
\hline X5 = Asset turnover & 0.10 & 0.15 \\
\hline \hline
\end{tabular}

S o u r c e: Author's own calculations - correlation statistically significant at a significant level of 0.05 (at a significant level of 0.01 - t-Student distribution).

Considering the values of Pearson's correlation coefficient calculated for the company $\alpha_{2}$ there can be observed a very strong positive correlation between Z'-score and return on assets and cumulated return on assets. This indicates that an increase in solvency in the company $\alpha_{2}$ is accompanied by a simultaneous increase in the involvement of assets for generating profit and an increase in the level of profit per a monetary unit of the involved assets. The conducted research shows a very weak positive correlation between the Altman Z'-score and financial liquidity and a weak negative correlation between solvency and asset turnover.

Verifying the correctness of the proposed solutions in the field of the conducted research based on the Altman model, it can be concluded that it allowed for the examination of the particular reasons of the existing phenomena. The analysis in the field of solvency of the cement industry companies under consideration provides precise information both on the course of organizational processes and the sources of their financing.

Analyzing the decision making model of the company $\alpha_{1}$ it can be noted that the priority is to maintain sustainable financial liquidity. The conducted research indicates a strong positive correlation between the level of the Altman Z'-score and financial liquidity. A high share of equity in the structure of to- 
tal liabilities provides stability to the company $\alpha_{1}$ in changing external conditions. The research indicates a strong positive correlation between the Altman Z'-score and capital market efficiency. This means that solvency is a decisive factor for the company in question.

Analyzing the decision-making model represented by the company $\alpha_{2}$ it can be observed that the priority is an increase in solvency achieved with an increase in quick liquidity. The conducted research shows a very strong positive correlation between the Altman Z'-score and return on assets ( $r=0.97)$ indicating that the company aims at the stimulation of the efficiency of using fixed and current assets to generate profit. The company $\alpha_{2}$ runs a quality policy (of high prices), which is reflected both in inventory turnover and the level of profitability. Building competitive position in the company $\alpha_{2}$ is based on creating a specific value for clients achieved by means of the quality of the provided products. The decision-making model of the company $\alpha_{2}$ is characterized by mutually adjusted and complimentary processes and decisions aimed at the achievement of competitive advantage in the sector of the cement market.

\section{THE OUTCOME OF THE RESEARCH PROCESS AND CONCLUSIONS}

The aim of the paper is the analysis of the information capacity of the selected instruments of the asessment of decison-making models in the investigated entities. To achieve the objective of the paper in the first stage of the research process there was used the multivariate model of E. I. Altman enabling early identification of the risk symptoms related to the continuation of the activity. In the second stage, to examine the strength and direction of linear correlation between decisive factors in organizational and financial processes in the cement industry companies there was used Pearson's correlation coefficient.

The conducted research indicates that the environment of the decisionmaking model in organizational and financial processes affects the performance of the cement industry companies, which means that the achievement of competitive advantage by the company requires the achievement of the appropriate level of profitability and solvency, while accomplishing the most important objective which is creating value for clients. The achievement of a particular kind of competitive advantage must take into account the market sector in which the company operates and the source of income in that sector.

Enterprises operating in a dynamic environment aim at achieving competitive advantage by using resources in optimized processes. The financial dimen- 
sion of the achieved competitive advantage is profitability (profit). The level of profitability in the cement industry companies is affected by the possessed resources and developed processes. The problem of decision-making models is important and up-to-date on account of the fact that decision-making models in organizational and financial processes in the cement industry companies must be considered as the enterprise activity at a certain time, which uses resources and optimizes processes of the activity to reduce costs or to create distinctive products with a simultaneous increase in value for clients, which allows to achieve sustainable competitive advantage and generate profits.

\section{DEFERENCES}

Ackoff R. L., Churchman C. W. (1957), An Introduction to Operations Research, New York, 22.

Akerlof G. A. (1970). The Marketfor ,Lemons': Quality Uncertainty and the Market Mechanism. Quarterly Journal of Economics, 488-500. http://dx.doi.org/10.2307/1879431.

Altman E. I. \& Hotchkiss E. (2007), Trudności finansowe a upadłość firm, Wyd. CeDeWu, Warszawa, 229-239.

Altman E. I. (1968). Financial Ratios, Discriminant Analysis and the Prediction of Corporate Bankruptcy. Journal of Finance, September, 589. http://dx.doi. org/10.1111/j.1540-6261.1968.tb00843.x.

Altman E. I. (1984). The Success of Business Failure Prediction Models: An International Survey. Journal of Baking and Finance, 171.

Bittel L. R. (2002), Krótki kurs zarządzania, Wydawnictwo PWN, Warszawa, 205.

Brdulak H. (2011), Nowoczesne modele biznesu w logistyce, 31 [in:] Strategie i logistyka w sektorze usług. Logistyka w nietypowych zastosowaniach, Witkowski, A. Baraniecka (eds.), Prace Naukowe UE we Wrocławiu 234, Wrocław.

Cebrowska T. (2006), Analiza finansowa, 680 [in:] Rachunkowość finansowa i podatkowa, PWN, Warszawa.

Griffin R. W. (2000), Podstawy zarządzania organizacjami, PWN, Warszawa, 270.

Grudzewski W. M., Hejduk I. (2006), Współczesne kierunki rozwoju nauk o zarządzaniu, 284 [in:] Nowe tendencje w nauce o organizacji i zarządzaniu, M. Hopej (eds.), Politechnika Wrocławska, Wrocław.

Jacobson C., Choi S. O. (2008). Success factors: public works and public private partnerships. International Journal of Public Sector Management, vol. 21, 637-657. $10.1108 / 09513550810896514$.

Konovalova N. (2014), Case Study Method Application When Studying Finance And Banking: Situation Description, Prague, 700-715. http://proceedings.iises.net/index.php ?action=proceedingsIndexConference\&id=7\&page=3 (accessed: 01.03.2015). 
Kościelniak H. (2008), Management of Capital Structure of Polish Stock Companies. Case Study, 46 [in:] Changes and Risk in Knowledge Based Economy. R. Lescroart, A. Pachura, M. Kozak (eds.), HEC „Blaise Pascal”, Luxemburg.

Kowalczyk J., Kusak A. (2006), Decyzje finansowe firmy, metody analizy, C.H. Beck. Warszawa, 1.

Krupski R., Niemczyk J., Stańczyk-Hugiet E. (2009), Koncepcje strategii organizacji. PWE, Warszawa, 167.

Magretta J. (2002). Why Business Models Matter, Harvard Business Review, 80(5), 92.

Nogalski B. (2009), Modele biznesu jako narzędzie reorientacji strategicznej przedsiębiorstw, MBA 2, 7. http://www.google.pl/url?sa=t\&rct=j\&q=\&esrc=s\&source=web\&c $\mathrm{d}=1 \&$ ved=0CCoQFjAA\&url=http\%3A\%2F\%2Fjml2012.indexcopernicus.com\%2Ffulltxt.php\%3FICID\%3D1064004\&ei=CCvIUvVDzJKFB9LagKAB\&usg=AFQjCNG7LDFom y3D8IzAQI0USaNh_sp24w (accessed: 04.01.2014).

Obłój K. (2007), Strategia organizacji, PWE, Warszawa, 60-123.

Romanowska M. (2004), Planowanie strategiczne, PWE, Warszawa, 30.

Siemińska E.(2002), Metody pomiaru i oceny kondycji finansowej przedsiębiorstwa, Wyd.: Dom Organizatora, Toruń, 206-207.

Skoczylas W., Waśniewski T. (2005), Analiza finansowa, 36 [in:] Encyklopedia rachunkowości, M. Gmytrasiewicz (ed.), Wyd. LexisNexis, Warszawa.

Skowron-Grabowska B. (2014). Business Models in Transport Services. Przegląd Organizacji, nr 1, 35-39.

Sobol E. (2000), Słownik wyrazów obcych, PWN, Warszawa, 732.

Stachowicz J. (2002), Polskie doświadczenia w kształtowaniu społeczeństwa informacyjnego, 289-290 [in:] Dylematy cywilizacyjno-kulturowe, L.H. Haber (eds.) AGH, Kraków.

Stewart D. M. (2002), Praktyka kierowania, PWE, Warszawa, 350.

Stoner J. A. F., Freeman R. E., Gilbert D. R. (2001), Kierowanie, PWE, Warszawa, 247. 